\title{
Lumbar Radiculopathy: a Descriptive Study on Red Flag and Neurologic Symptoms in Dr. Hasan Sadikin General Hospital Bandung
}

\author{
Astrid Feinisa Khairani, ${ }^{1}$ Kuheinderan Radha Krishnan, ${ }^{2}$ \\ Umar Islami, ${ }^{3,4}$ Siti Aminah Sobana ${ }^{5}$ \\ ${ }^{1}$ Department of Biomedical Sciences, Faculty of Medicine, Universitas Padjadjaran, Sumedang, Indonesia, \\ ${ }^{2}$ Medical Undergraduate Study Program, Faculty of Medicine, Universitas Padjadjaran, Sumedang, Indonesia, \\ ${ }^{3}$ Graduate School of Biomedical Sciences Master Program, Faculty of Medicine, Universitas Padjadjaran, \\ Bandung, Indonesia, ${ }^{4}$ Department of Histology and Medical Biology, Faculty of Medicine, Universitas Islam \\ Bandung, Bandung, Indonesia, ${ }^{5}$ Department of Neurology, Faculty of Medicine, Universitas Padjadjaran/ \\ Dr. Hasan Sadikin General Hospital, Bandung, Indonesia
}

\begin{abstract}
Over $80 \%$ of the adult population will experience an episode of low back pain (LBP). Low back pain is a pain in the lumbosacral region. When it progresses, which may be identified earlier with signs of a red flag, the manifestation might become radiculopathy. Radiculopathies are nerve root disease which may show signs of neurologic symptoms from the sensory, motoric, or autonomic origin. This study to help identify the clinical characteristics of a red flag in low back pain patients, which became lumbar radiculopathy for prognostic and diagnostic use. It is a descriptive quantitative cross-sectional study of medical records from patients hospitalized with complaints of low back pain with lumbar radiculopathy between January 2013-December 2015 in the Department of Neurology, Dr. Hasan Sadikin General Hospital, Bandung. It identifies a specific red flag and neurogenic symptoms. Patients most affected were housewives (26\%), females (60\%), and middle-aged adults (31\%). The highest recorded symptom being sensory (76\%), the highest progression was sensory to motoric (59\%), affected by all three neurologic symptoms (39\%), and trauma was the highest red flag recorded (48\%). Low back pain patients who have signs of red flag show a high tendency to develop radiculopathy, which shows neurologic symptoms. If left untreated earlier, it may become a permanent disability.
\end{abstract}

Key words: Low back pain, radiculopathy, red flag

\section{Radikulopati Lumbar: Studi Deskriptif Gejala Klinis Red Flag dan Gejala Neurologis di RSUP Dr. Hasan Sadikin Bandung}

\begin{abstract}
Abstrak
Lebih dari $80 \%$ populasi penduduk dewasa akan mengalami episode low back pain (LBP). Low back pain merupakan nyeri pada bagian tulang belakang regio lumbo-sakral. Pada saat rasa sakitnya bertambah berat, gejala berbahaya dapat menjadi awal perkembangan LBP menjadi radikulopati. Radikulopati merupakan penyakit saraf pada daerah radiks neuron berupa gejala sensorik, motorik, dan otonomik. Penelitian ini bertujuan mengidentifikasi karakteristik gejala klinis tanda berbahaya (red flag) pada pasien LBP yang berlanjut menjadi radikulopati lumbar sebagai alat bantu diagnostik dan prognostik. Penelitian ini menggunakan metode penelitian cross-sectional kuantitatif deskriptif dari rekam medis pasien yang dirawat dengan diagnosis LBP dan radikulopati lumbar antara bulan Januari 2013-Desember 2015 di Departemen Ilmu Penyakit Saraf, RSUP Dr. Hasan Sadikin, Bandung. Penelitian ini mengidentifikasi gejala klinis red flag spesifik dan neurologis. Pasien yang terkena terutama ibu rumah tangga (26\%), wanita (60\%), usia dewasa pertengahan (31\%). Gejala yang tercatat paling banyak adalah sensorik (76\%), perkembangan progresif sensorik ke motorik (59\%), mengalami gangguan ketiganya (39\%), dan trauma menjadi penyebab red flag yang paling tinggi (48\%). Pasien LBP yang memiliki gejala tanda berbahaya (red flag) memiliki kecenderungan tinggi berkembang menjadi radikulopati yang menunjukkan gejala neurologis. Jika tidak diobati lebih awal, ini dapat mengakibatkan kecacatan permanen.
\end{abstract}

Kata kunci: Low back pain, radikulopati, red flag 


\section{Introduction}

Sometime during life, over 80 percent of the population will experience an episode of low back pain (LBP). ${ }^{1}$ LBP defined as the complaint of pain in the area of spinal or paraspinal structures in the lumbosacral region. ${ }^{2}$ According to the Global Burden of Disease Study 2015 (GBD 2015), the expert group stated that among the top ten high burden diseases and injuries, LBP is one of them with an average number of DALYs (disability-adjusted life years). It is higher than HIV, tuberculosis, road injuries, lung cancer, chronic obstructive pulmonary disease, and preterm birth complications. ${ }^{3}$ Low back pain, if left untreated with the red flag, may cause a more severe medical condition. Low back pain remains a common condition among primary care patients with an estimated lifetime prevalence of $13.8 \%$ for chronic pain and $80 \%$ for any episode of pain..$^{4-6}$

Low back pain affecting both men and women, with age, is the primary risk factor, as it occurs secondary to the degenerative process within the spinal column. ${ }^{7}$ Symptoms typically begin in midlife, with men often affected in the 40 os while women are affected in the 50 a and $605 .{ }^{8,9}$ Females have a higher risk in specific populations, with physically demanding careers such as service in the military. Patients commonly present with back pain that is associated with their radiculopathy. By definition, radiculopathy describes pain that radiates down the legs and is often described by patients as electric, burning, or sharp. The most common underlying cause of radiculopathy is irritation of a particular nerve, which can occur at any point along the nerve itself and is most often a result of a compressive force. The diagnosis of the causative agent and subsequent treatment starts with a thorough physical exam.

The term red flags are symptoms and signs that show a possible manifestation of more serious medical conditions, which may cause permanent disability and, if not managed correctly, may even lead to death. ${ }^{10}$ These red flags seen in LBP patients, when neglected without treatment, may become radiculopathy. Radiculopathies are a disease of nerve roots from inflammation or impingement from a tumor or a bony spur. ${ }^{11}$ One form of radiculopathy is one that affects the lumbar region. The prevalence of lumbar radiculopathy varies from about $2.2-8 \%$, and the incidence ranges from $0.7-9.6 \%$. About 76.1\% of lumbar radiculopathies involve the $\mathrm{L}_{5}$ and $\mathrm{S} 1$ nerve roots. ${ }^{12}$ Lumbar radiculopathy refers to a pathologic process involving the lumbar roots causing radicular symptoms in a lower extremity. The nerve root pathology arises primarily from direct neural compression irrespective of whether the etiology is an acute herniated or displaced disc, bony spurs, foraminal stenosis, central stenosis, or hypermobility of a vertebral segment. ${ }^{13}$

While a substantial burden on our health-care system, low back pain is typically self-limited, with most cases resolving after conservative management in 6 to 8 weeks. ${ }^{14}$ Most low back pain is nonspecific; patients with low back pain may have neurologic impairments or a severe underlying pathology that requires timely and accurate diagnosis. Low back pain that is due to severe pathology occurs between $1 \%$ and $4 \%$ of the time and has been generally classified as related to 4 etiologies: fracture, malignancy, infection, and cauda equina syndrome..$^{15-17}$ Appropriate identification of these diagnoses for their management is essential. Therefore, due to the prevalence, burden, and associated healthcare cost of low back pain, it is paramount to know the characteristics to detect severe disease.

However, the data on LBP and its red flag, such as lumbar radiculopathy, is extremely limited in Indonesia, specifically in the Department of Neurology in Dr. Hasan Sadikin General Hospital, Bandung. This study conducted to help in finding out the clinical characteristics of a red flag in LBP patients with lumbar radiculopathy by identifying the red flag. The neurologic symptoms are sensory, motoric, or autonomic to help identify and diagnose that these symptoms are an underlying problem, which can become something even more severe if left untreated. This study aimed to help identify red flags in these patients and the possible neurologic symptoms to occur in them.

\section{Methods}

This study uses an observational descriptive quantitative cross-sectional study as a method of study. Medical records used in this study were from January 2013-December 2015. Subjects used for this study are LBP patients with lumbar radiculopathy that hospitalized in the Department of Neurology in Dr. Hasan Sadikin 
General Hospital, Bandung.

A rough table is stating the needed characteristics such as occupation, sex, age, symptoms to appear, the progression of symptoms, and the red flag first created. The data obtained for the first symptoms to appear also classified into acute, sub-acute, and chronic. This data was obtained by cross-checking medical records for the required data from the historytaking as well as the physical exam portion of the medical record. Incomplete medical records, medical records that did not state the characteristics clearly, and patients who did not have signs of LBP with lumbar radiculopathy as well of the red flag excluded. The data tabulated and analyzed accordingly.

This study approved by the Health Research Ethics Committee of the Faculty of Medicine, Universitas Padjadjaran, Bandung by ethics approval letter number: 571/UN6.C1.3.2/KEPK/ PN/2016.

\section{Results}

In this study, the data used was secondary data from medical records of patients from the Department of Neurology in Dr. Hasan Sadikin General Hospital, Bandung. A total of 54 patient's data recorded fit the inclusion criteria. Based on the data, five tables created with the corresponding variables.

Based on the data obtained in the study from the occupational demography data (table not inserted), most of the patients who suffered from LBP with lumbar radiculopathy admitted into Dr. Hasan Sadikin General Hospital were housewives, $26 \%$ of the total patient population. The next majority was that the manual laborers were $17 \%$. However, 17 patients did not have proper employment status and classified as N/A
Table 1 Distribution of LBP Patients with Lumbar Radiculopathy and Their Age

\begin{tabular}{ccc}
\hline $\begin{array}{c}\text { Range of Age } \\
\text { (Years) }\end{array}$ & $\begin{array}{c}\text { Number } \\
(\mathbf{n = 5 4 )}\end{array}$ & Percentage \\
\hline $11-20$ & 1 & 2 \\
$21-30$ & 9 & 17 \\
$31-40$ & 5 & 9 \\
$41-50$ & 11 & 20 \\
$51-60$ & 17 & 31 \\
$61-70$ & 9 & 17 \\
$71-80$ & 1 & 2 \\
$81-90$ & 1 & 2 \\
\hline
\end{tabular}

(not assessed). Other occupations which recorded were pensioners, security guards, policemen, students, privately employed staff, and selfemployed staff.

From the data describes the gender demographic data of the patients (table not inserted), females have a higher tendency, which was a percentage of $60 \%$ to LBP with lumbar radiculopathy as compared to males at $40 \%$.

Table 1 describes the distribution of age about LBP patients with lumbar radiculopathy, as obtained from the data. The age range between 51-60 years had the highest frequency of patients, with a percentage of $31 \%$. The data does show that the middle-aged adults were more affected by LBP and lumbar radiculopathy as compared to those of younger age or older.

Table 2 shows the data for the first symptoms with lumbar radiculopathy, as well as the time for the manifestation. That be within the period of acute (less than three weeks), which showed $18 \%$ sensory, $5 \%$ motoric, and $2 \%$ autonomic.

Table 2 Distribution of LBP Patients with Lumbar Radiculopathy and Their First Symptom with the Duration for Manifestation of the Symptoms

\begin{tabular}{lcccc}
\hline Onset of Symptoms & $\begin{array}{c}\text { Sensory } \\
(\mathbf{n = 4 1 )} \\
\mathbf{7 6 \%}\end{array}$ & $\begin{array}{c}\text { Motoric } \\
(\mathbf{n = 1 2}) \\
\mathbf{2 2 \%}\end{array}$ & $\begin{array}{c}\text { Autonomic } \\
(\mathbf{n = 1}) \\
\mathbf{2 \%}\end{array}$ & $\begin{array}{c}\text { Total } \\
(\mathbf{n = 5 4})\end{array}$ \\
\hline$<3$ weeks & $10(18 \%)$ & $3(5 \%)$ & $1(2 \%)$ & 14 \\
3 weeks -3 months & $15(28 \%)$ & $7(13 \%)$ & $0(0 \%)$ & 22 \\
$>3$ months & $16(30 \%)$ & $2(4 \%)$ & $0(0 \%)$ & 18 \\
\hline
\end{tabular}


Table 3 Distribution of LBP Patients with Lumbar Radiculopathy and Their Progression from the First Symptom

\begin{tabular}{lcc}
\hline $\begin{array}{l}\text { Symptom } \\
\text { Progression }\end{array}$ & $\begin{array}{c}\text { Number } \\
(\mathbf{n = 5 4 )}\end{array}$ & Percentage \\
\hline Sensory-motoric & 32 & 59 \\
Sensory-autonomic & 11 & 20 \\
Motoric-sensory & 7 & 13 \\
Motoric-autonomic & 4 & 8 \\
\hline
\end{tabular}

For the sub-acute phase ( 3 weeks to 3 months), $28 \%$ showed sensory symptoms, $13 \%$ motoric, and $\mathrm{o} \%$ autonomic. For chronic (more than three months), 30\% showed sensory symptoms, $4 \%$ showed motorically, and no patients recorded with autonomic first symptoms.

Table 3 shows the progression of the symptoms from the first symptom to appear in the patients. The progression from a sensory symptom to a motoric symptom seems to be higher at $59 \%$. Twenty percent of patients have a progression from sensory symptoms to autonomic symptoms. Progression from autonomic symptoms to sensory or motoric symptoms seems to be the lowest.

Table 4 describes the current condition of the patients, 12 (22\%) had sensory problems only, 1 patient had an only motoric symptom, 12 (22\%) patients had both sensory and motoric problems,

Table 4 Distribution of LBP Patients with Lumbar Radiculopathy and Their Current Symptoms

\begin{tabular}{lcc}
\hline Symptoms & $\begin{array}{c}\text { Number } \\
(\mathbf{n = 5 4 )}\end{array}$ & Percentage \\
\hline Sensory only & 12 & 22 \\
Motoric only & 1 & 2 \\
Sensory+motoric & 12 & 22 \\
Sensory+ & 7 & 13 \\
$\quad$ autonomic & & \\
Motoric+ & 1 & 2 \\
$\quad$ autonomic & & 39 \\
$\quad$ autonomic & 21 & \\
\hline
\end{tabular}

Table 5 Distribution of LBP Patients with Lumbar Radiculopathy and the Signs of Red Flag

\begin{tabular}{lcc}
\hline $\begin{array}{l}\text { Red Flag } \\
\text { Category }\end{array}$ & $\begin{array}{c}\text { Number } \\
(\mathbf{n = 5 4 )}\end{array}$ & Percentage \\
\hline Cancer & 18 & 33 \\
Infection & 8 & 15 \\
Trauma & 26 & 48 \\
Neurogenic deficit & 2 & 4 \\
\hline
\end{tabular}

sensory and autonomic dysfunction was recorded in 7 (13\%) patients, 1 patient had motoric and autonomic problems, and 21 (39\%) patients had all 3 problems.

Table 5 describes the data obtained on the red flag signs of the patients divided into 4 subcategories, which were cancer, infection, trauma, and neurologic deficits. It is seen that the common red flag seen in patients of LBP with lumbar radiculopathy has a red flag sign of trauma, which was $48 \%$. Cancer-related signs were the next most seen in the patients with $33 \%$. Neurogenic signs were recorded with $4 \%$, and infection signs were recorded at $15 \%$.

Table 6 describes the working diagnosis of the patients admitted to the hospital. Lumbar radiculopathy patients based on the cause being trauma is the highest, with $28 \%$, the next was cauda equina syndrome based on cancer as the cause was the second highest with $24 \%$. However, overall, the diagnosis for patients who come in with low back pain is almost similar.

\section{Discussion}

This study showed that patients with low back pain who had the red flag signs could progress to a more serious medical condition. The conditions could cause a neurologic dysfunction, may it be sensory, motoric, or even autonomic. Thus, the population observed were low back pain patients as a passage to the more severe condition becoming lumbar radiculopathy. The result was also to help strengthen the primary goal for both prognostic and diagnostic functions. The data showed that the majority of the patients admitted with low back pain and having a red flag have had a progression in symptoms from either sensory, motoric, or even autonomic. Most of the patients 
Table 6 Distribution of LBP Patients with Lumbar Radiculopathy and Their Working Diagnosis

\begin{tabular}{lcc}
\hline Symptoms & $\begin{array}{c}\text { Number } \\
\text { (n=54) }\end{array}$ & Percentage \\
\hline Cauda equina syndrome based on trauma & 8 & 15 \\
Cauda equina syndrome based on cancer metastasis & 13 & 24 \\
Cauda equina based on spondylitis Tb & 3 & 5 \\
Low back pain based on degenerative, trauma, fracture & 3 & 5 \\
Low back pain based on sequel stroke & 2 & 4 \\
Lumbar radiculopathy based on trauma & 15 & 28 \\
Lumbar radiculopathy based on spondylitis Tb, infections & 3 & 6 \\
Lumbar radiculopathy based on cancer metastasis & 5 & 9 \\
Lumbar myeloradiculopathy based on spondylitis Tb & 2 & 4 \\
\hline
\end{tabular}

admitted did not only have one red flag but multiple red flags.

It observed that homemakers have the highest tendency to acquire LBP with radiculopathy with a percentage of $26 \%$. The similar result showed by Bener et al. ${ }^{18}$ which stated that the prevalence of LBP patients was $53 \%$ of the population. In the study done by Akter, ${ }^{19}$ homemakers are a risk factor for LBP due to the physical strain the reach doing household work such as standing for long periods or squatting for long periods.

The study showed that gender does also affect the prevalence of this problem as females had a higher prevalence (59\%) to LBP with lumbar radiculopathy as compared to males. This data corresponds with the study done by Wang et al., ${ }^{20}$ which had stated that the prevalence of LBP was higher in females rather than males due to many factors, mainly hormonal. However, a study by Fillingim et al. ${ }^{21}$ carried out in Sweden and Norway did suggest that although the prevalence of LBP is higher in females, Norway men had a higher lifetime prevalence of LBP.

Age was another factor that contributed to LBP in patients. Middle-age adults were the highest in the data recorded to have low back pain with radiculopathy. In this study, data showed that between the ages of $51-60$ is the highest incidence of LBP with radiculopathy to $31 \%$. However, the incidence of the problem begins to increase from the age of 31 years old and above. The result corresponded to the BP6.24 paper updated in 2013, stating the prevalence of LBP peaks between the ages of 35 to $55 .{ }^{2}$ Aging factors such as osteoporosis, lack of exercise, obesity, smoking for a woman due to menopause causing estrogen production to decrease, causing bone formation to decrease as well..$^{22}$

From the type of symptoms first appear in LBP patients with lumbar radiculopathy, out of 54 patients' 41 showed signs of sensory disturbance either from pain or numbness. Twelve patients showed signs of motoric disturbance, such as being unable to walk correctly or stand properly, and one patient had autonomic problems such as weak anal sphincter or unable to control bowel movements or urinary processes. This data shows that in the study done by Shankar et al., ${ }^{23}$ which stated that chronic LBP did have autonomic dysfunctions such as a reduced vagal tone and an increased sympathetic tone does not correspond with the findings from the study. For the time factor majority of the symptoms progressed from one category to another from a time frame of 3 weeks to 3 months. This study showed that subacute patients had the highest rate of symptoms showing, followed by chronic and acute. However, this does show that even though a patient is at the acute, sub-acute, or chronic stage, they may still develop the symptoms from either sensory, motoric, or even go to autonomic. Patients also can start with a motoric symptom and progress to sensory or autonomic dysfunctional conditions. The study relates to a study done by Friedman et al. ${ }^{24}$ in which $30 \%$ of patients with acute LBP had a functional impairment three months later.

The data also was recorded to obtain the current condition of the patients. From that, 21 
patients had shown all three signs of symptoms may it be sensory, motoric, or even autonomic. Twelve patients showed they had only sensory problems, and 12 showed they had both sensory and motoric problems, and seven patients had sensory and autonomic problems. No patients had only autonomic symptoms stating that patients usually started with at least a sensory or motoric problem before it progressed to autonomic. Patients also showed that even though they were in the acute, sub-acute, or even the chronic period, they still could progress to any other symptom. Gregory et al. ${ }^{25}$ state that patients who come in with sensory problems can later develop into more severe motor and sensory problems.

From the first symptom to appear, there was a progression to another symptom in most of the patients. Most of the progression, however, started from sensory problems and later progressed to either motoric or autonomic problems. The highest rate of progression was from sensory to motoric seen in 32 patients (59\%). The next highest progression was from sensory to autonomic, as seen in 11 patients (20\%). However, the progression from motoric to another symptom was low as compared to sensory, and there was no progression from autonomic symptoms. The symptom is usually due to the affected part of the spinal route, whereby externally affected roots usually show symptoms of sensory problems. As it affects deeper into the spinal column, it affects motoric and autonomic functions as well.

Many of the patients had morethan one red flag. The data obtained classified the red flag into four major categories, which were infection, trauma, neurogenic deficits, and cancer. According to the data obtained, the typical red flag seen in patients of LBP with lumbar radiculopathy has a $48 \%$ red flag sign of trauma, which was cancer-related signs were the next most seen in the patients with a $33 \%$. Neurogenic signs recorded with $4 \%$ and infection signs recorded at $15 \%$.

The working diagnosis of the patients recorded as well. The data showed that the majority of the patients had had a similar diagnosis, and the causative agent almost the same in many. Lumbar radiculopathy caused by trauma was the highest recorded in the patients with 15 people diagnosed. For patients diagnosed with cauda equina syndrome, many of them caused by a metastasis of some form of cancer followed by patients who had cauda equine caused by trauma. There were two patients diagnosed with lumbar myeloradiculopathy caused by spondylitis tuberculosis and low back pain caused by a stroke. Overall, it did prove that a previous study that disc degeneration was the leading cause of low back pain worldwide. ${ }^{25}$

Many patients diagnosed with this problem have not been treated to the full extent to fully cure their symptoms or prevent their symptoms from progressing, as seen in the data obtained from this study.

\section{Conclusion}

The clinical characteristics of the red flag were gender, middle-age adults, history of trauma, followed by cancer, infection, and neurogenic deficits. Low back pain patients who have signs of red flag show a high tendency to develop radiculopathy, which shows neurologic symptoms. If left untreated earlier, it may become a permanent disability. Intimate knowledge of the signs, symptoms, and red flag warning signs is a necessity.

\section{Conflict of Interest}

All authors declare to have not to conflict of interest in publishing this article.

\section{Acknowledgments}

Researchers would like to thank the Department of Neurology Faculty of Medicine, Universitas Padjadjaran/Dr. Hasan Sadikin General Hospital, Bandung, for the support and help implement this study.

\section{References}

1. Ferguson SA, Merryweather A, Thiese MS, Hegmann KT, Lu ML, Kapellusch JM, et al. Prevalence of low back pain, seeking medical care, and lost time due to low back pain among manual material handling workers in the United States. BMC Musculoskelet Disord. 2019;20(1):243.

2. Duthey B. Background paper 6.24: low back pain. In: Kaplan W, Wirtz VJ, MantelTeeuwisse A, Stolk P, Duthey B, Laing R, editors. Priority medicines for Europe and 
the world: 2013 updated. Geneva: WHO Press; 2013. p. 6.24-1-29.

3. GBD 2015 Disease and Injury Incidence and Prevalence Collaborators. Global, regional, and national incidence, prevalence, and years lived with disability for 310 diseases and injuries, 1990-2015: a systematic analysis for the Global Burden of Disease Study 2015. Lancet. 2016;388(10053):1545-602.

4. Raison NT, Alwan W, Abbot A, Farook M, Khaleel A. The reliability of red flags in spinal cord compression. Arch Trauma Res. 2014;3(1):e17850.

5. Delitto A, George SZ, van Dillen L, Whitman JM, Sowa G, Shekelle P, et al. Low back pain: clinical practice guidelines linked to the international classification of functioning, disability, and health from the orthopaedic section of the American Physical Therapy Association. J Orthop Sports Phys Ther. 2012;42(4):A1-57.

6. Hooten WM, Cohen SP. Evaluation and treatment of low back pain: a clinically focused review for primary care specialists. Mayo Clin Proc. 2015;90(12):1699-718.

7. Wong AY, Karppinen J, Samartzis D. Low back pain in older adults: risk factors, management options and future directions. Scoliosis Spinal Disord. 2017;12:14.

8. Stochkendahl MJ, Kjaer P, Hartvigsen J, Kongsted A, Aaboe J, Andersen M, et al. National Clinical Guidelines for non-surgical treatment of patients with recent onset low back pain or lumbar radiculopathy. Eur Spine J. 2018;27(1):60-75.

9. Kreiner DS, Hwang SW, Easa JE, Resnick DK, Baisden JL, Bess S, et al. An evidencebased clinical guideline for the diagnosis and treatment of lumbar disc herniation with radiculopathy. Spine J. 2014;14(1):180-91.

10. Verhagen AP, Downie A, Popal N, Maher C, Koes BW. Red flags presented in current low back pain guidelines: a review. Eur Spine J. 2016;25(9):2788-802.

11. Yusuf M, Finucane L, Selfe J. Red flags for the early detection of spinal infection in back pain patients. BMC Musculoskelet Disord. 2019;20(1):606.

12. Tawa N, Rhoda A, Diener I. Accuracy of clinical neurological examination in diagnosing lumbo-sacral radiculopathy: a systematic literature review. BMC Musculoskelet Disord.
2017;18(1):93

13. Berry JA, Elia C, Saini HS, Miulli DE. A review of lumbar radiculopathy, diagnosis, and treatment. Cureus. 2019;11(10):e5934.

14. Patrick N, Emanski E, Knaub MA. Acute and chronic low back pain. Med Clin North Am. 2016;100(1):169-81.

15. Williams CM, Henschke N, Maher CG, van Tulder MW, Koes BW, Macaskill P, et al. Red flags to screen for vertebral fracture in patients presenting with low-back pain. Cochrane Database Syst Rev. 2013;(1):CDoo8643.

16. Underwood M, Buchbinder R. Red flags for back pain. BMJ. 2013;347:f7432

17. Schoenfeld A, Laughlin M, Bader JO, Bono CM. Characterization of the incidence and risk factors for the development of lumbar radiculopathy. J Spinal Disord Tech. 2012;25(3):163-7.

18. Bener A, Dafeeah EE, Alnaqbi K. Prevalence and correlates of low back pain in primary care: what are the contributing factors in a rapidly developing country. Asian Spine J. 2014;8(3):227-36.

19. Akter S. Prevalence of low back pain among the housewives [dissertation]. Dhaka: Bangladesh Health Professions Institute (BHPI); 2014 [cited 2016 January 31]. Available from: http://dspace.crpbangladesh.org:8080/xmlui/bitstream/ handle/123456789/118/504\%20Sonia\%20 Akter.pdf? sequence $=1$ \&isAllowed $=\mathrm{y}$.

20. Wang C, Yu X, Yan Y, Yang W, Zhang S, Xiang $\mathrm{Y}$, et al. Tumor necrosis factor- $\alpha$ : a key contributor to intervertebral disc degeneration. Acta Biochim Biophys Sin (Shanghai). 2017 Jan;49(1):1-13.

21. Fillingim RB, King CD, Ribeiro-Dasilva MC, Rahim-Williams B, Riley JL $3^{\text {rd }}$. Sex, gender, and pain: a review of recent clinical and experimental findings. J Pain. 2009;10(5):447-85.

22. Wáng YXJ, Wáng JQ, Káplár Z. Increased low back pain prevalence in females than in males after menopause age: evidences based on synthetic literature review. Quant Imaging Med Surg. 2016;6(2):199-206.

23. Shankar N, Thakur ML, Tandon OP, Saxena AK, Arora S, Bhattacharya N. Autonomic status and pain profile in patients of chronic low back pain and following electro acupuncture therapy: a randomized 
control trial. Indian J Physiol Pharmacol. 2011;55(1):25-36.

24. Friedman BW, Gensler S, Yoon A, Nerenberg R, Holden L, Bijur PE, et al. Predicting threemonth functional outcomes after an ED visit for acute low back pain. Am J Emerg Med.
2017;35(2):299-305.

25. Gregory DS, Seto CK, Wortley GC, Shugart CM. Acute lumbar disk pain: navigating evaluation and treatment choices. Am Fam Physician. 2008;78(7):835-42. 